\title{
Biosimilars patent litigation in the EU and the US: a comparative strategic overview
}

\author{
Brian J Malkin, Esq
}

\begin{abstract}
Biosimilars are highly similar versions of reference biological products, some with the potential to be deemed 'interchangeable' by regulatory bodies, such as the US Food and Drug Administration. Biosimilar patent litigation continues to evolve as biosimilars enter new global markets. This manuscript takes a look at patent litigation strategies in a more developed biosimilars market, the European Union (EU) and compares them to a developing biosimilars market, the US, where the litigation strategies are still unfolding. This manuscript is a first in a two-part series, which will later include patent litigation strategies in Canada and Japan, as well as updates in the EU and the US.
\end{abstract}

Keywords: Biosimilars, follow-on biologicals, Inter Partes Review, litigation, opposition, patent

\section{Introduction}

The European Union (EU) was the one of the first highly regulated areas to develop a legal and regulatory framework for the approval for highly similar versions of innovator biological products, called 'biosimilars' or 'follow-on biologicals'. While formal consideration of a biosimilar approval pathway began in the EU as early as 2001 [1], the European Commission first amended its market authorization provisions to include 'similar biological medicinal products' in 2003 [2], and issued its first general biosimilar guidance in 2005 [3]. The European Medicines Agency's (EMA) first approval under the new similar biological medicinal product pathway was Sandoz's somatropin called Omnitrope $^{\circledR}$ in 2006 [4]. The EU currently has 19 biosimilars referencing five innovator biological products [4]. The US biosimilar pathway began in 2010 with the enactment of the Biosimilars Patent Cooperation and Innovation Act (BPCIA) [5] and has one approved biosimilar, Sandoz's filgrastim-sndz [6] called Zarxio ${ }^{\circledR}$ in 2015 [7]. While the EU's legal system is complicated by the lack of a unified patent litigation system that requires a multicountry patent litigation approach, the US's biosimilar patent litigation has been complicated thus far by biosimilar applicants and the reference biological product (RBP) applicants picking and choosing what portion of the default patent litigation exchange system to utilize. Despite the differences between the prevalent litigation tactics in the EU and the US, as biosimilar approvals become more globalized, it will be increasingly important to appreciate these differences and consider how biosimilars patent litigation arguments and outcomes in one venue can benefit and be utilized in other venues, even if in different countries or legal systems.

\section{Biosimilar regulatory overview}

The EU and the US have similar regulatory standards for biosimilars that would enable a manufacturer to make a biosimilar product that could in theory satisfy both regulatory standards, assuming that the RBP is the same. In the EU, a biosimilar must demonstrate similar quality and biological activity and demonstrate no meaningful differences in terms of safety or efficacy between the biosimilar and the RBP. EMA develops productspecific guidances through a consultative process that establishes common comprehensive comparability and immunogenicity studies required for biosimilar applicants to demonstrate biosimilarity for approval. As part of these requirements, biosimilar applicants are expected to conduct a product-by-product analysis using state-of-the-art bioanalytics and manufacturing along with clinical and regulatory experiences to support biosimilarity.

In the US, biosimilars must be highly similar to the RBP notwithstanding minor differences in clinically-inactive components. To demonstrate biosimilarity, there must be no clinically meaningful differences in terms of safety, purity, or potency-essentially safety and efficacy. So far, US Food and Drug Administration (FDA) has not developed product-specific guidances, preferring to issue more general guidances related to a product-specific development approach. Instead, each biosimilar product has its own approval requirements, developed in a stepwise approach, following multiple comparisons of the proposed biosimilar product to the RBP using state-of-the-art bioanalytics, where the required clinical studies and other study requirements are determined by how similar the products are as well as the observed bioanalytical differences.

Unique to the US, FDA may determine a biosimilar product is 'interchangeable' with the RBP. An interchangeable product may be substituted for the RBP without the intervention of the healthcare provider who prescribed the RBP. FDA may determine that a biosimilar product is interchangeable with the RBP if the biological product meets that highly biosimilar standard above plus: (1) the biosimilar product will produce the same clinical result as the RBP in any given patient; and (2) if administered more than once to an individual, the risk in terms of safety or diminished efficacy or alternating or switching between using the biosimilar and RBP is no greater than the risk of using the RBP without such alternation or switch. But FDA has said that while by law it could accept for filing and review an interchangeable biosimilar application, in practice it would not approve a biosimilar as interchangeable without some confirmatory market evidence. In this context, FDA suggested that perhaps five years of post-approval safety data would be sufficient for an applicant to submit a supplement to its previously approved biosimilar application, requesting a finding of interchangeability. So in the near future, most biosimilar litigation 
in the US will likely not involve an interchangeable biosimilar product.

\section{EU biosimilar patent strategies European patent opposition}

In Europe, the opposition process to a patent granted by the European Patent Office (EPO) is the most common approach for challenging the RBP's patents. In part, this appears to be because it enables a biosimilar manufacturer to challenge a RBP's key patents in a single forum rather than multiple nation state patent courts. For example, oppositions were filed for epoetin (RBP Epogen ${ }^{\circledR}$ [Amgen]), filgrastim (RBP Neupogen ${ }^{\circledR}$ [Amgen]), infliximab (RBP Remicade ${ }^{\circledR}$ [Johnson and Johnson/ Janssen]), insulin glargine (RBP Lantus ${ }^{\circledR}$ [Sanofi]), and somatropin (RBP Gentropin ${ }^{\circledR}$ [Pfizer]). EPO has 38 contracting states and provides unified patent prosecution and opposition with the option for national patents by applicant choice after prosecution. Oppositions may be filed by any public member(s) except the proprietor within nine months after the patent is granted, which has public notice.

But an opposition has limited grounds to revoke a patent, including: (1) the subject matter is not patentable; (2) the invention was not disclosed clearly or completely enough for one skilled in the art to perform the invention; or (3) the subject matter extends beyond the content of the application filed. From an opposition, there are a number of possible outcomes: (1) the opposition is rejected and the patent is maintained as granted; (2) the patent is maintained in amended form with a new published specification; or (3) the patent is revoked. Initial opposition decisions may be appealed within two months, and countries may have conflicting rules whether they stay, i.e. halt further legal process, national patent infringement actions while an opposition and any associated appeal is pending. The median time for an appeal is close to three years, which is the same approximate median time for an opposition for patents concerning pharmaceutical/biotechnology products.

\section{National patent litigation}

Concurrently or following an opposition, biosimilars patent litigation may begin in member countries; however, litigation in each county requires detailed knowledge of that country's national patent litigation procedures. A RBP manufacturer may choose to bring an infringement action or a biosimilar applicant may bring a declaratory judgement action for one or more patent(s) that may be at issue. Given the differences in patent litigation rules and biosimilars regulatory applications, there may be advantages to bring an initial biosimilars patent litigation in the anticipated primary biosimilar markets, the place of business or manufacture of the RBP or biosimilar, or based on a perceived jurisdictional favouritism for the action. For example, Amgen brought its filgrastim patent infringement litigation in Germany, which is the only EU country with separate courts for infringement and invalidity and is preferred for patent enforcement. Teva, on the other hand, brought its declaratory judgement action against Amgen's patents for the same product in the UK, which has specialized patent courts and a high rate of patent invalidity judgements. Because each country has its own court system where patent holders may enforce their patents, there is the possibility for conflicting patent enforcement decisions in different countries, where RBP and biosimilar manufacturers may pursue national patent litigations in member countries simultaneously or successively.

In this context, biosimilar manufacturers have employed a variety of tactics, depending on a particular member country's perceived market and the strength of the patents at issue. One option is to wait out key patents to expire in each member country, as Hospira suggested it would do for Remicade ${ }^{\circledR}$ (infliximab) [8]. Another is to launch at risk, which is often considered in The Netherlands and the UK given their higher rate of invalidity decisions and accelerated proceedings with no or lower punitive/ treble damages, i.e. damages higher than calculated or treble (triple damages), which is punitive to make up for intentional infringement. In other situations, to avoid a preliminary injunction, i.e. an injunction entered by a court prior to a final determination of the merits of a legal case, to restrain a party from going ahead with a course of conduct or compelling a party to continue with a course of conduct until the case has been decided, issued by the judge ex parte, i.e. without hearing the other side, a biosimilar manufacturer may file a 'protective letter' to inform the court beforehand in detail of its non-infringement and invalidity arguments. Such letter may request the court to take account of its arguments and may also request to be heard to prevent the exparte measure. But it is at the court's discretion to what extent the court will take account of this protective letter. Biosimilar manufacturers are more likely to consider protective letters in countries where patent proceedings take longer or tend to favour the patent holder, e.g. Belgium and Germany.

Yet other measures seek to avoid disruptive patent litigation prior to product approval or before product launch. For example, Hospira sought to invalidate certain patents for trastuzumab (RBP Herceptin ${ }^{\circledR}$ [Genentech/Roche]) in the UK even before product approval. The primary patent for Heceptin ${ }^{\circledR}$ with a supplementary protection certificate (SPC, a type of extension of the term or expiration date of a patent based on a product approval) expired on 28 July 2014, and two additional dosage and composition patents had been held invalid in an opposition with appeals pending. Hospira challenged those two patents and won a lower court decision in April 2014 [9] and an appeal on February 2015 [10], finding both patents invalid, where it further obtained a declaration of non-infringement for certain trastuzumab formulations. In some instances, a biosimilar manufacturer may also begin its national merit invalidity or non-infringement proceedings early to help prevent preliminary injunctions

\section{Unitary patent/Unified Patent Court}

One option that may be possible for biosimilars litigation in the EU in the future is patent litigation in a proposed Unified Patent Court (UPC). The concept is that a unitary patent (UP) will be a single patent with a unitary effect for all contracting states and a unified court system for all patent litigations. Many EU countries have joined the UP/UPC with notable exceptions being Croatia, Poland and Spain. The European Parliament and European Council approved the EU UP package in December 2012, with participating Member States signing the Agreement for a UPC in February 2013. The UPC needs to be ratified by at least 13 signatory states to come into force including France, Germany, and the UK, and has so far been ratified by Austria, Belgium, Denmark, France, Luxembourg, Malta and Sweden. 
A potential fly in the ointment was an action brought by Spain before the EU Court of Justice, challenging the UP and applicable translation arrangements, which was dismissed on 5 May 2015 [11]. While the UPC is waiting for a final ratification by sufficient Member States, the infrastructure for a UPC is building within the EU.

A UPC has the advantages of one application leading to one patent, with one patent litigation action leading to one decision for all participating 25 states in a streamlined procedure. The streamlined litigation procedure has a series of steps: (1) Written Procedure (two writs per party normally on infringement and two on validity, if included); (2) Interim Procedure (includes all steps to comprehensively prepare the case for an oral hearing including conferences); (3) Preparation for Oral Hearing (all steps to prepare an oral hearing for the panel); (4) Oral Hearing (managed by three judges - two multinational and one non-state national - including witnesses, evidence, pleadings and cross-examination); (5) Decision on the Merits (includes decisions on injunctions, damages, accounting, validity and costs of proceedings); and (6) Appeals (based on points of law and matters of fact brought within two months of decision of the Court of First Instance or within 15 days of an order, where rehearings appear to be exceptional).

At this point, there is no UPC, but when ratified and effective, there will likely be a parallel system structure, i.e. a UPC and a national patent system, which has led to the question whether these will lead to an inadmissible double patent protection. While the new UPC system at this point has no case law, there is already contradictory case law in the participating Member States, leading to some initial uncertainty on how the UPC system will work. Some initial thoughts are that RBP holders will use the UPC system to protect their intellectual property in all participating states and continue to protect EPO and national patents in key markets either for a first litigation or as part of a fall-back plan.

\section{US biosimilar patent strategies \\ Patent dance}

The US biosimilar pathway includes new patent litigation provisions (aka 'the patent dance') that provide for a default exchange of information leading to at least two distinct phases of patent litigation with possible ramifications for failure to follow this default exchange. The proposed exchange mechanism differs in many ways from Hatch-Waxman patent litigation for small molecule drugs including: (1) there is no book like the 'Orange Book' that lists patents including claims to the active ingredient, product, or approved use(s) of the product [12]; (2) there are no patent certifications to FDA indicating potential patent challenges or a 30-month stay options for patent challenges by the RBP holder; (3) it relies on a voluntary exchange of information including the biosimilars application and information that describes the process(es) used to manufacture the biological product in the application and relevant patents as determined by the RBP holder and biosimilar applicant; (4) there are ramifications for not participating in the voluntary exchanges including limited litigation rights; (5) there are relatively short timeframes for the patent exchanges that, when followed, would yield a lengthy cycle before any infringement action after FDA accepts the biosimilar application for filing; (6) it envisions multiple patent litigation cycles following the initial exchange of patent lists, 180 days prior to commercial product launch, and post launch.
When everything is followed as provided in the default preapproval patent litigation process, the following steps are indicated:

\section{Notifications}

- Within 20 days of FDA notification of the biosimilar's application acceptance, the applicant sends notice of filing and a copy of its application to the RBP holder and such other information that describes the process or processes used to manufacture the biological product that is the subject of such application and may provide to the RBP holder additional information requested by or on behalf of the RBP holder (under statutory or otherwise-agreed-to confidentiality terms).

- Within 60 days, the RBP holder provides biosimilar applicant with a list of all patents for which it could bring a claim of patent infringement and a list of patents it is willing to license to the applicant.

- Within 60 days, the biosimilar applicant provides: (1) its own list of patents that it believes the RBP holder could bring a claim of patent infringement; (2) detailed statements (like in HatchWaxman Act) why, claim-by-claim, each patent is invalid, unenforceable, or not infringed by the applicant; (3) may include a statement when the applicant intends to launch, e.g. after expiration of one or more patents; and (4) whether it would consider a license to one or more patents listed by the RBP holder.

- Within 60 days, the RBP holder provides: its own detailed statements why, claim-by-claim, it believes each listed patent is valid, enforceable and infringed by the biosimilar applicant.

\section{Litigation suits}

- For 15 days of good-faith negotiations, the biosimilar applicant and RBP holder attempt to agree on a list of patents to litigate prior to product launch as an 'artificial' act of infringement, i.e. 'artificial' because there is no infringement until a product is marketed, but the litigation proceeds based on the biosimilar applicant's assertion that it intends to market its biosimilar product, if approved, prior to expiration of one or more patents.

- If they fail to agree, the biosimilar applicant and RBP holder each compile their own list, with the biosimilar applicant responding first, and the RBP holder must reply within five days of provision of the biosimilar applicant's list.

- The RBP holder's list may not exceed the number of patents in the biosimilar applicant's list, and if the biosimilar applicant's list contains no patents, then the RBP holder may include one patent in the patent litigation list.

- Within 30 days, the RBP holder must bring suit against the biosimilar applicant with respect to the patents included in the lists (a 'timely infringement suit' and phase one).

- The RBP holder may only recoup a royalty if:

○ The RBP holder fails to bring a timely infringement suit; or ○ Following a timely infringement suit, the action is dismissed without prejudice or not prosecuted to judgement in good faith.

- Newly issued or licensed patents must be added to the patent lists within 30 days of issuance or licensing.

- The biosimilar applicant must provide 180 days advance notice prior to commercial launch, upon which (as to the patents to the lists as modified by newly issued or licensed patents):

○ The RBP holder or biosimilar applicant can seek a declaratory judgement; and

- The RBP holder can sue for a preliminary injunction before the date of first marketing (phase two). 
Like generic drug patent litigation following the Hatch-Waxman Act, which established a generic drug approval process in the US, US biosimilars patent litigation has been off to a bumpy start. The initial US biosimilars patent litigation actions were filed before the related biosimilars applications were filed, e.g. Sandoz's version of Enbrel ${ }^{\circledR}$ (etanercept) and Celltrion/Hospira's version of Remicade $^{\circledR}$ (infliximab). However, both of these actions were denied by the courts because they were premature, so a similar strategy is unlikely to be followed by subsequent biosimilar applicants.

Two other biosimilar patent litigation actions appear to have included some but not all elements of the patent dance [13]. Reasons to avoid the patent dance include: (1) the maximum allotted times for each party in the patent dance may mean 250 days before a lawsuit after FDA has accepted the biosimilar application for filing, but FDA has a 10-month review cycle ( 300 days), which could lead to an FDA approval prior to any substantive patent ruling; (2) the proposed confidentiality provisions and need for patent certainty before launch may not be viewed as insufficient for the biosimilar applicant to provide the RBP holder its proprietary application; (3) FDA's review process appears to be separate from the patent dance; (4) the default patent information and list exchange leading to pre-launch patent litigation is expensive and unproven; (5) following market approval, there still exists the risk of another lawsuit for the marketed product; and (6) the EU model suggests alternative patent challenges via the Inter Partes Review (IPR) mechanism (a post-grant patent challenge at the United States Patent and Trademark Office (USPTO) versus the federal court system) and possibly the International Trade Commission (another type of patent challenge that may provide for an injunction for imported, infringing goods) or wait for relevant patents to expire, i.e. 12-year exclusivity means core patents may have limited life left.

One of the two actions is moving forward on the first FDAapproved biosimilar application, Sandoz's version of Amgen's Neupogen ${ }^{\circledR}$ (filgrastim), called Zarxio ${ }^{\circledR}$ (filgrastim-sndz). Amgen filed in a California District Court a lawsuit under California's Unfair Competition Law and for conversion for failure to follow the default patent information exchange mechanism that would lead to pre-market patent litigation. In the same court, Amgen also moved for a preliminary injunction to prevent Sandoz's market entry of Zarxio ${ }^{\circledR}$ pending a disposition on the merits. Here, Sandoz failed to provide its biosimilar license application within 20 days of FDA's notice of filing or other elements of the patent dance, yet ultimately provided Amgen with its biosimilars license application, resulting in the present lawsuit and a separate patent infringement suit for one patent, which has been stayed pending resolution of the procedural patent exchange suit. Sandoz disagreed with the Unfair Competition Law charge, arguing that the provisions of the default patent exchange and pre-market litigation are optional. The California Court denied Amgen's motion for a preliminary injunction and motion for a judgement on the pleadings. In conjunction with this action, Amgen filed a citizen petition with FDA to request that FDA not file any biosimilar application in its discretion, unless the applicant agreed to follow all procedures under the patent dance. FDA denied this petition on 25 March 2015, pending any contrary outcome in the litigation [14]. Amgen has appealed the lower court's decision, and the matter is pending in the Federal Circuit, which heard oral arguments on the pleadings on 3 June 2015. The main issues in the case are whether a biosimilar applicant needs to engage in all steps of the patent dance to take advantage of the biosimilars approval pathway, or whether some or all of the steps are optional, and whether a biosimilar applicant can only provide 180-day notice of commercial launch after approval of the biosimilars license application or if notice of an intent to market following application approval is sufficient.

While Celltrion/Hospira failed to meet the standard for a declaratory judgement for several Janssen patents related to Remicade $^{\circledR}$ (infliximab) prior to filing its application, it appears that Janssen has filed a patent litigation suit along with allegations that Celltion/Hospira failed to follow mandatory patent dispute procedures under the BPCIA, demanding that such procedures be followed. In this instance, Janssen has asserted that while Celltrion/Hospira timely provided its biosimilar license application to Janssen and followed some patent dispute procedures, Celltrion/Hospira failed to disclose required manufacturing process information requested by Janssen to develop its list of potential patents to litigate. Janssen has also asserted that Celltrion/Hospira failed to follow procedures under the BPCIA by illegally shortening the patent litigation negotiation process from the list of patents exchanged by Janssen and that Celltion/ Hospira failed to provide an effective 180-day notice of commercial launch, because such notice may only be provided after application approval, which has not yet occurred. The issues are therefore similar as with the Amgen $v$. Sandoz case, namely whether all or some patent dance steps need to be followed according to the BPCIA and what constitutes notice of 180-day advance notice of commercial launch. No dispositive motions have been decided in this case related to these pending issues. And at this point, it is uncertain what information has been exchanged for the two other publicly noticed and pending biosimilar license applications filed by Apotex referencing Amgen's Neupogen ${ }^{\circledR}$ (filgrastim) and Neulasta ${ }^{\circledR}$ (pegfilgrastim).

\section{Additional considerations}

At this point, there appears to be limited patent litigation challenges in the EU with a preference to patent issuance challenges and some limited country patent challenges. There are many unresolved issues. As more biosimilar product applications are filed in the US, will there be greater incentives for testing patents in certain country markets before the US, especially if there is a UP/UPC, or will all major patent litigation continue to be in the US? Once FDA approves interchangeable biosimilars, how will that affect European patent challenges, especially for bridging products, i.e. similar or same biological products marketed in both the EU and the US? Will the Federal Circuit require biosimilar applicants to follow all steps of the patent dance, some of them, or none of them, at the discretion of the parties? Depending on the Federal Circuit's decision in the Amgen $v$. Sandoz case, will Congress amend the US biosimilars approval or litigation pathway? Will other tactics that challenge patents outside the US Federal courts such as IPRs in the USPTO or litigation in the International Trade Commission become more frequent strategies similar to how oppositions are used in the EU, because biosimilar patent litigation is too unwieldy? We are just at the tip of the iceberg when it comes to biosimilar patent challenges.

The subsequent manuscript will look at patent challenges in Canada and Japan, along with updates for the EU and the US. 


\section{Index of abbreviations/acronyms \\ IPR - Inter Partes Review}

A trial proceeding conducted by the Patent Trial and Appeal Board (PTAB) at the United States Patent and Trademark Office (USPTO) to review the patentability of one or more claims in a patent only on a ground that could be raised under 35 U.S.C. \&\$ 102 or 103, and only on the basis of prior art consisting of patents or printed publications. The PTAB is created by statute and includes statutory members and Administrative Patent Judges. The PTAB is charged with rendering decisions on appeals from adverse examiner decisions, post-issuance challenges to patents, and interferences.

UP - Unitary Patent

A proposed new type of European patent that would be valid in participating Member States of the EU with such unitary effect registered upon grant, replacing validation of the European patent in the individual countries concerned. The unitary effect means a single renewal fee, a single ownership, a single object of property, a single court (the Unified Patent Court), and uniform protection, meaning that revocation as well as infringement proceedings are to be decided for the unitary patent as a whole rather than for each country individually.

\section{UPC - Unified Patent Court}

A proposed common patent court for participation of all Member States of the European Union that would hear cases regarding infringement and revocation proceedings of European patents (including unitary patents) valid in the territories of the participating states, with a single court ruling being directly applicable throughout those territories. Requesting unitary patents upon the grant of certain European patents will be possible from the establishment of the UPC.

\section{Author's notes}

Patent litigation for this manuscript is used broadly to mean to bring or defend a legal patent action, which may be in a court or before another judicial body, e.g. a patent review board, such as the European Patent Office or the United States Patent and Trademark Office, or another official governmental or quasi-judicial body, where a patent may be enforced or a patent challenged in terms of validity, infringement, or enforceability.

Disclosure of financial and competing interests: The author is an employee of McGuireWoods LLP. The author has no competing interests to disclose for this manuscript. The author wishes to note that he is a licensed patent attorney and also practices food and drug law in the US, not the European Union (EU). As a result, his comments regarding the legal system in the EU are based on his research and not his licensure to practice law in the EU. As noted in the manuscript, litigation in each jurisdiction requires detailed knowledge of that jurisdiction's litigation procedures and should be in consultation with appropriate counsel.

Provenance and peer review: Commissioned; externally peer reviewed.

\section{References}

1. European Medicines Agency. Guideline on comparability of medicinal products containing biotechnology-derived proteins as active substance: non-clinical and clinical issues. 17 December 2003. EMEA/CPMP/3097/02/Final [homepage on the Internet]. 2003 Dec 22 [cited 2015 Aug 4]. Available from: http://www.ema.europa. eu/docs/en_GB/document_library/Scientific_guideline/2009/09/WC500003963.pdf

2. Commission Directive 2003/63/EC of 25 June 2003 amending Directive 2001/83/ EC of the European Parliament and of the Council on the Community code relating to medicinal products for human use. J Eur Union. 2003;L159:46-94.

3. European Medicines Agency. Guideline of similar biological medicinal products. 30 October 2005. EMEA/CHMP/437/04 [homepage on the Internet]. [cited 2015 Aug 4]. Available from: http://www3.bio.org/healthcare/followonbkg/GuidelineonSimilarBiologicalProducts.pdf

4. European Medicines Agency. EMA list of approved biosimilars [homepage on the Internet]. [cited 2015 Aug 4]. Available from: http://www.ema.europa.eu/ ema/index.jsp?curl=pages $\% 2$ Fmedicines $\% 2$ Flanding $\% 2$ Fepar_search.jsp\&mid= WC0b01ac058001d124\&searchTab=searchByAuthType\&alreadyLoaded=true\& isNewQuery=true\&status=Authorised\&keyword=Enter+keywords\&searchType= name\&taxonomyPath=\&treeNumber=\&searchGenericType=biosimilars\&generi csKeywordSearch=Submit.

5. Patient Protection and Affordable Care Act, Pub.L. No. 111-148, 124 Stat. 119, tit. VII, subtit. A (2010).

6. FDA called this a "placeholder nonproprietary name," because FDA is still deciding its nonproprietary naming procedures.

7. U.S. Food and Drug Administration. FDA approves first biosimilar product Zarxio [homepage on the Internet]. 2015 [cited 2015 Aug 4]. Available from: http:// www.fda.gov/NewsEvents/Newsroom/PressAnnouncements/ucm436648.htm

8. PR Newswire. Hospira launches first biosimilar monoclonal antibody (mAb) Infectra $^{\mathrm{TM}}$ (infliximab) in major European markets [homepage on the Internet]. [cited 2015 Aug 4]. Available from: http://phx.corporate-ir.net/phoenix. zhtml?c=175550\&p=irol-newsArticle\&ID=2016883

9. British and Irish Legal Information Institute. Hospira UK Limited v. Genentech Inc. [2014] EWHC 1094 (Pat) (10 Apr 2014) [homepage on the Internet]. [cited 2015 Aug 4]. Available from: http://www.bailii.org/ew/cases/EWHC/ Patents/2014/1094.html

10. Hospira (UK) Limited v. Genentech, Inc., [2015] EWCA Civ. 57. 6th February 2015 [homepage on the Internet]. [cited 2015 Aug 4]. Available from: http://phx. corporate-ir.net/phoenix.zhtml?c=175550\&p=irol-newsArticle\&ID=2016883

11. Court of Justice of the European Union. The Court dismisses both of Spain's actions against the regulations implementing enhanced cooperation in the area of creation of unitary patent protection. Press release no 49/15. 5 May 2015 [homepage on the Internet]. 2015 May 5 [cited 2015 Aug 4]. Available from: http://curia. europa.eu/jcms/upload/docs/application/pdf/2015-05/cp150049en.pdf

12. FDA publishes a "Purple Book" that includes biologics license applications (BLAs) with interchangeability ratings for biosimilars, approval dates, and product names.

13. Because these litigations are pending and some related court papers have been filed under seal, there is a limited record to ascertain which elements were actually followed. Based on the public filings, it appears that the information exchange was somewhat other than that proposed in the statute, and this article reflects the author's review of public information available from the associated court dockets as of July 1, 2015.

14. Requests FDA adopt policies and practices in their acceptance and review of biosimilar applications that will provide for the orderly implementation and efficient functioning of the Biologics Price Competition and Innovation Act (BPCIA). FDA Docket No. FDA-2014-P-1771 [homepage on the Internet]. [cited 2015 Aug 4]. Available from: http://www.regulations.gov/\#!docketDetail;D=FDA-2014-P-1771 DOI: 10.5639/gabij.2015.0403.026

Copyright (c) 2015 Pro Pharma Communications International 